Т. М. Мішеніна

\title{
ВИВЧЕННЯ СЛОВОТВОРЧОГО ПОТЕНЦІАЛУ АФІКСОЇДІВ В УКРАЇНСЬКІЙ МОВІ У ЗМІСТІ ФАХОВОЇ ПІДГОТОВКИ МАЙБУТНІХ ФІЛОЛОГІВ
}

Мішеніна Т. М. Вивчення словотворчого потенціалу афіксоїдів в українській мові у змісті фахової підготовки майбутніх філологів.

У статті розкрито словотворчий потенціал афіксоїдів в українській мові у змісті фахової підготовки майбутніх філологів: статус афіксоїдів, вплив афіксоїдів на посилення аглютинативних тенденцій в українській мові. Розроблено систему завдань, спрямованих на вивчення словотворчого потенціалу афіксоїдів у змісті навчальних дисциплін науково-предметної підготовки.

Ключові слова: афіксоїд, префіксоїд, суфіксоїд, словотворчий потенціал, майбутні вчителі філологічних спеціальностей. 
Мишенина Т. М. Изучение деривационного потенциала аффиксоидов в украинском языке в содержании профессиональной подготовки будущих филологов.

В статье раскрыт деривационный потенциал аффиксоидов в украинском языке в содержании профессиональной подготовки будущих филологов: статус аффиксоидов, влияние аффиксоидов в усилении аглютинативных тенденций в украинском языке. Разработана система заданий, направленных на изучение деривационного потенциала аффиксоидов в содержании учебных дисциплин научнопредметной подготовки.

Ключевые слова: аффиксоид, префиксоид, суффиксоид, деривационный потенциал, будущие учителя филологических специальностей.

Mishenina T. M. Study derivational building in ukrainian affixoids language in the content of training future philologists/

The article discloses a derivative affixoids potential in the Ukrainian language in the content of training future philologists: status affixoids influence in strengthening affixoids aglyutinativnyh trends in the Ukrainian language. A system of tasks aimed at the study of potential diversion affixoids in the content of academic disciplines scientific subject training.

Key words: affixoids, prefiksoid, suffiksoid, derivational potential future teachers philological specialties.

Зміст філологічних і психолого-педагогічних наук останніми роками значно змінюється відповідно до розвитку соціокультурної дійсності й наукових шкіл. Це знаходить послідовне втілення в розробленні програм наукових дисциплін із унесенням до змісту інновацій у філології, педагогіці і психології. Основні тенденції, які відображають окреслені зміни, виявляються в таких принципах побудови змісту навчальних дисциплін у ВНЗ:

1) інтеграція змісту уможливлюе вивчення психологопедагогічних і філологічних наук на основі трансдисциплінарності принцип міжпредметності;

2) гуманізація змісту і методів навчання передбачає вивчення наукових об'єктів відповідно до їх людинотворчого ресурсу принцип антропоцентризму;

3) інноваційні процеси передбачають переосмислення функцій у структурі наук - принцип неофункціоналізму;

4) трансформаційні процеси передбачають виявлення i пояснення системних зв'язків елементів у межах наукової галузі принцип експланаторності.

У процесі вивчення словотворчого потенціалу афіксоїдів в українській мові у процесі фахової підготовки майбутніх учителів філологічних спеціальностей необхідним $є$ врахування окреслених принципів за умови діяльнісного підходу до фахової підготовки 
майбутніх філологів.

Запровадження діяльнісного підходу до організації навчання, що передбачає створення умов задля активної позиції суб'єкта діяльності, завдяки чому відбуватиметься свідоме, міцне засвоєння ним певного досвіду, уможливлює активну участь студентів у процесі навчання; окреслює можливості прикладного використання знань у реальних умовах, наприклад, у проектувальній діяльності як одному із способів оптимізації фахової підготовки студентів-філологів.

Важливими для нашого дослідження $є$ праці 3 питань діяльнісного підходу до навчання учнів у загальноосвітніх закладах (С. Гончаренко, С. Караман, В. Коржуєв, П. Кубрушко, В. Ледньов, О.Пометун, В. Попков, О. Савченко, Д. Чернилевський); психологічні концепції діяльності (Л. Виготський, П. Гальперін, В. Давидов, О. Леонтьєв, С. Рубінштейн); теорії формування особистості в навчально-виховному процесі (К. Абульханова-Славська, Л. Божович, С. Максименко, В. Роменець, Т. Яценко).

Виробленню стратегії нашого дослідження сприяли методологічно спрямовані дослідження В. Беспалька, В. Бондаря, Б. Гершунського, С. Гончаренка, I. Зязюна, Г. Костюка, В. Кременя, В. Лозової, Н. Ничкало, І.Підласого, В.Рибалки, В. Семиченко, О. Савченко, О.Сухомлинської.

Запровадження діяльнісного підходу до навчання майбутніх учителів філологічних спеціальностей дозволить розв'язати суперечність між потребою у формуванні предметної компетентності майбутніх учителів філологічних спеціальностей як важливого складника їх фахової підготовки у вищому навчальному закладі і відсутністю наукового розв'язання цієї проблеми у вищих педагогічних навчальних закладах, дидактичних i методичних розробок, практичних рекомендацій для викладачів із зазначеного питання.

Мета публікації - розкрити словотворчий потенціал афіксоїдів в українській мові у змісті фахової підготовки майбутніх учителів філологічних спеціальностей.

Вивчення словотворчого потенціалу передбачено навчальними дисциплінами циклу науково-практичної підготовки: Культура мовлення (орфографічні норми); Латинська мова (лексичні норми); Сучасна українська літературна мова (лексичні та морфемнословотвірні норми); Стилістика української мови та риторика; Лінгвістичний аналіз тексту (стилістичні норми). 
Система організації навчальної діяльності майбутніх учителів філологічних спеціальностей має враховувати досягнення психологопедагогічних і філологічних наук, що уможливлює розгляд фахової підготовки майбутніх учителів філологічних спеціальностей як процес створення ефективного навчального середовища 3 його суб'єктами діяльності. Саме на цих засадах має базуватись управління системою підготовки майбутніх учителів філологічних спеціальностей з регіональним і вітчизняним рівнями освітньо-кваліфікаційної характеристики задля формування предметної компетентності.

Вивчення словотворчого потенціалу афіксоїдів в українській мові передбачає такі етапи: 3'ясування сутності розглядуваного явища; розгляд афіксоїдів на орфографічному, морфемнословотвірному, лексичному і стилістичному рівні; спостереження над динамічними змінами, що відбуваються у мовній системі; оволодіння методикою вивчення аналізованого мовного явища.

Афіксоїд - проміжна афіксоподібна морфема, що є частиною складного або складноскороченого слова, здебільшого співвідносною 3 основою и коренем, яка повторюється 3 тим самим значенням у багатьох словах, наближаючись за словотвірними функціями до афіксів.

Сучасна українська мова засвідчує афіксоїди у складних словах, що можна обгрунтувати залежністю творення складних слів від лексики й синтаксису. Типізація вираження словотвірної й лексичної семантики за допомогою складних слів пов'язана 3 однотипністю формальних перетворень різнорівневих одиниць, зокрема словосполучень у речення $[2 ; 3 ; 6 ; 7]$.

Афіксоїди, не втрачаючи тісного зв'язку 3 кореневими морфемами, формують словотвірні типи аналогічно до префіксів і суфіксів [4, с. 30-31].

Функціональними є афіксоїди, що у прикінцевій позиції в українській мові втратили зв'язки зі спільнокореневими словами: -ом (сприймається як суфіксальна): міома, неврома, саркома, трахома, папілома тощо. При утворенні розглядуваних термінів використовується суфіксальний спосіб творення іменників (nephritis, meningitis, myoma, leucocytus, leucocytosis). Грецькі суфікси іменників становлять: -is (ознака хвророби); -it is (запалення); -ӧта (пухлина); -osis (перевищення норми). Пор.: -онко (сприймається як префіксоїдна): онкологія, онкосфера [4, с. 31; 5]. 
Завдання: Утворіть складні слова за формулою: запалювальний прочес + орган:

Довідка: -оt- - вухо; -derm- - шкіра; -stomatit- - pom.

Завдання: Запишіть терміни латинською мовою, виокремте терміноелементи, укажіть їх значення:

Офтальмологія, патогенез, ендоскопія, дистонія, поліартрит, гастроскопія, аритмія, фармакотерапія, артроліз.

Завдання: Поясніть значення термінів:

Neuralgia, anaesthesia, hypoaesthesia, hydrotherapia, hydrophobia.

Використовуваним при утворенні термінів також $є$ спосіб складання основ: одонталгія, невралгія, гістологія, гідротерапія, гастроскопія, кардіографія, кардіологія.

Завдання: Виокремте значущі елементи в наведених термінах, запишіть українською мовою, поясніть значення:

Haemogramma, ophthalmia, bacteriaemia, hydrophobia, phytotherapia, pharmacologia, cardiologia, pathologia, odontalgia, angiographia, angiospamus.

Завдання: Утворіть терміни, поясніть їх значення:

а) рослина, ліки, вода, повітря, жар + ... (о) therapia;

б) голова, нирка, м'яз, шлунок $+\ldots$ (о) algia.

Завдання: Утворіть за допомогою сполучного голосного «о» терміни із терміноелементів із таким значенням:

Серце + наука; ліки + наука; кров + наука; клітина + наука; тканина + наука.

Префіксоїдні запозичені основи широко використовують словотворчі елементи складних слів авіа-, авто-, агро-, біо-, відео-, геліо-, гідро-, електро-, зоо-, кіно-, палео-, радіо-, сочіо-, стерео-, теле-, турбо-, фоно-, фото- тощо: авітор, автомобіль, агропромисловий, біоенергетика, відеоролик, геліосистема, електростанція, зоонім, кінофільм, радіоуправління, сочіометрія, стереосистема, телепередача, турбомеханізм, фонотека, фотоательє.

Префіксоїди набувають стандартного значення «який стосується тієї предметної ділянки»: радіотовари, радіотелетайп, радіотелефон, радіотермографія, радіотуманність, радіоустановка, радіотрансляція, радіотеплолокачія, радіочикл, радіохвиля, радіоформа, радіочент, радіочастота, радіошум, радіощогла.

Водночас спостерігаємо терміни, значення яких засвідчує більш широкий діапазон реалізації додаткових значеннєвих компонентів унаслідок тематичного розшарування дериватів унаслідок полісемії 
твірної основи. Зокрема, у термінах радіоавтограф, радіоаеронавігачійний, радіоаеронавігачія, радіоакумулятор, радіоакустичний, радіовишка, радіолабораторія префіксоїд радіореалізує значення «передавання на відстань без дротів інформації за допомогою радіохвиль»; радіовиступ, радіожурнал, радіоінформачія, радіолекторій, радіолекиія, радіоспектакль, радіотеатр, радіошуми «радіопередача»; у термінах радіодеталь, радіозавод, радіоелемент, радіомайстерня, радіопересувка, радіотовари, радіоустановка - «те саме, що радіоприймач».

Завдання: Користуючись Словником української мови, поясніть значення термінів. Зверніть увагу на тематичне розшарування:

а) фото/альбом, фото/аматор, фото/апарат, фото/архів, фото/ательє, фото/виставка, фото/вікно, фото/вітрина, фото/газета, фото/галерея, фото/добірка, фото/документ, фото/експозиція, фото/етюд, фото/журналіст, фотолжурналістка, фото/знімок, фото/знімання, фото/знімальний, фото/зображення, фото/ілюстрачія;

б) стерео/апаратура, стерео/діапозитив, стерео/екран, стерео/ефект, стерео/звук, стерео/звучання, стерео/канал, стерео/ кіно, стерео/кінокамера, стерео/кінотеатр, стерео/компаратор, стерео/листівка, стерео/магнітофон, стерео/механіка, стерео/ мікроскоп, стерео/музика, стерео/навушники, стерео/телебачення, стерео/фотографія, стерео/хімія.

Завдання: Ознайомтеся 3 наведеними прикладами термінів. Зробіть висновок про словотворчий потенціал іншомовних елементів, поясніть значення.

«Відео - 1. Галузь масової культури, пов'язана із записом та відтворення відеоінформації, технічні засоби, що забезпечують цю галузь. 2. розм. «Те ж саме, що відеофільм»:

В інтернеті можна дивитися навіть відео; Глядачеві часом не вистачає насиченого відеоряду, який частково компенсує закадрований текст-роз'яснення; Нечуючим че видалося абсурдом, а ті, хто навчає дітей жестовій мові, попросили записи ефірів для використання як навчального відеопосібника (Україна молода).

«Aydio - перша частина складних слів, що вказує на зв'язок із звуком, слухом, способом запису і відтворення звукової інформації»:

До речі, судді досі не вирішили, як бути із документальними фільмами, аудіовізуальними записами, які обидві адіо те долучити до справи»; Нам потрібно заздалегідь формувати позитивний імідж Чернігова. Задля цүього пропонуємо взаємний обмін рекламних носїв, а 
також відео- та аудіороликів з інформацією про туристичний потенціал з іншими містами України та містами-партнерами Чернігова за кордоном»; До видання увійшло 200 віршів письменнииі, з яких 50 публікуються вперше. До збірки додається аудіодиск» (Україна молода).

В українській мові використовуваними є питомі й запозичені основи, що співіснують. Особливістю їх функціонування $є$ те, що запозичені афіксоїди переважають у науковому стилі (у складі термінів); питомі - здатні бути компонентами фразеологізмів. Пор.: водогін; (аqиа - лат.) акваплан; (hydr- - гр.) zідросепаратор; (water англ.) ватерполо.

Завдання: Зробіть висновки щодо словотворчого потенціалу питомих й іншомовних компонентів терміносистеми української мови.

Водогін, водомір, акваланг, акваплан, аквамобіль, акваторія, акваріум, гідраріум, гідротерапія, гідроаеродром, гідробіологія, гідрологія, гідропульт, гідросепаратор, гідроліз, ватержакет, ватерполо, ватерлінія.

Завдання: Доберіть приклади термінів 3 основами, що співіснують у мові. Подайте коментар щодо особливостей функціонування термінів з такими основами (земле-, гео-; біо-, життє-; геліо-, сонце; тепло-, термо -; пис-, -граф; -мір, -метр; -нос, -фор; -люб, -філ).

Зауважимо, що залежно від галузі основні моделі термінів утворюються відповідно до тенденції: перевага грецького або латинського елемента. Наприклад, моделі медичних термінів (клінічна термінологія) мають у першій позиції основу грецького іменника або прикметника (основу грецької назви органа, тканини): nеuroma, gastroscopia, haematologia, otitis, dermatitis (неврома, гастроскопія, гематома, отит, дерматит). Для порівняння наводимо грецькі корені-синоніми латинських іменників: -neur- / nervus; -gastr-, -stomach-/ventriculus; -haem-/ sanguis; -ot-/auris; -derm- / cutis.

Завдання: Запишіть терміни по-латині, виокремте грецькі терміноелементи, укажіть їх значення: офтальмологія, патогенез, радіотерапія, артроліз, неврастенія, кардіографія, гематома, енцефаліт, гістогенез, кардіоліз, кардіофобія, бактеріємія.

Запозичені основи можуть наближатися до префіксів і суфіксів залежно від таких лінгвістичних умов:

1) видозміна форми афіксоїда;

2) позиція у слові (препозиція вимагає приєднання сполучного 
голосного; постпозиція передбачає поєднання запозиченої основи 3 нульовою флексією або одним суфіксом та флексією): -card- кардіолог - стенокардія; -bi(о)- - біометрія, біологія - анабіоз; -phago- - фагоцитоз - орнотофаг; -phobia- - гідрофобія - русофоб.

Завдання: Визначте статус запозичених основ. Обгрунтуйте думку.

1. Графологія, графометрія - барограф, кардіограф, міограф, гемотографія.

2. Логопед, логограма - ларинголог, гастролог, алерголог, кардіологія.

3. Невропат, телепат - патологія, патогенез, патофізіолог.

Завдання: Спрогнозуйте терміни відповідно до позиції запозичених основ. Зробіть висновок про їх словотворчий потенціал $\mathrm{i}$ сферу функціонування: андро- / -андрія; бласто- / -бласт; морфо- / -морф, морфізм; адіо те-/-антроп; фоно-/-фон.

У сучасній українській мові виокремилися групи запозичених основ, що мають продуктивність у пре- та постпозиції: 1) препозиція: гемо-; ефіро-; імуно-; мото-; механо-; техно-; хіміо-; 2) постпозиція: -гамія; -дром; -скоп, -скопія; -стат; -тека; -фікація; -циид: гемограма, гематома, ефіротерапія, ефіромісткий, імунодефіцит, мотодром, механочикл, технопарк, хіміобіогенез, моногамія, аеродром, термоскоп, мікроскоп, гігроскопія, фільмотека, теплофікачія, геночид, інсектицид, екоцид.

Завдання: Визначте статус запозичених основ у наведених словах. Зробіть висновок.

Полігамія, електроскоп, гематома, мотоцикл, гігроскоп, геліостат, аеростат, фонотека, кінотека, гербіцид.

На сучасному етапі розвитку української мови триває процес адаптації запозичених основ на рівні лексикалізації [1; 4, с. 88]: aydio, відео, кіно, мото, метро, максі, міні, радіо, стерео, фото.

В епоху інформатизації розвиток відеотехніки, потреба у зв'язку 3 цим у нових номенах зумовили словотвірну активність латинської за походженням основи відео (з лат. - дивлюся, бачу). Відповідно, основа відео у структурі кількох слів відеотелефон, відеограма, відеосигнал, відеофонограма [8, с. 127] стає згодом більш продуктивною: з'являються дво- і трикомпонентні похідні з цією основою

Основа відео входить до складу назв: а) технічних засобів для знімання і відтворення відеозапису (відеоапаратура, відеоплейєр, відеотехніка); б) назв приміщень i закладів для створення i 
демонстрації відеопродукції (відеоб’єднання, відеоцентр); в) назв видів відеопродукції (відеоматеріал, відеотелеметр).

Засвідчено словотвірну активність основи латинського походження aydio, семантика якої пов'язана зі слуховим сприйняттям інформації, музики: аудіоапаратура, аудіокасета, аудіотехніка.

Завдання: Порівняйте значення запозичених основ. Поясніть сутність явища лексикалізащії. Визначте статус запозичених основ: відео, невідм., с.; відео/апаратура, відео/версія, відео/гра, відео/диск, відео/зал, відео/запис, відео/зображення, відео/інженер, відео/ інформація, відео/камера, відео/касета, відео/кліп, відео/магнітофон, відео/матеріал, відео/піратство, відео/плівка, відео/приставка, відео/ програвач, відео/прокат, відео/режисер, відео/реклама, відео/ринок, відео/ролик, відео/ряд, відео/салон, відео/сигнал, відео/стрічка, відео/ телефон, відео/техніка, відео/фільм.

У сучасній українській мові афіксоїди становлять потужний словотворчий ресурс, посилюючи аглютинативні тенденції: телеграф автотелеграф, радіоавтотелеграф; навігація - аеронавігачія, радіоавіанавігація; телеметрія - біотелеметрія, космобіотелеметрія.

Завдання: Подайте коментар щодо розвитку аглютинативних тенденцій в українській мові: кінодраматургія, радіодрама, фотокінотехніка, радіокіноустановка, кінофотолабораторія, радіолокачійно-оптичний, радіокартографування, телерадіокомплекс, мікрорадіоприймач, мікрорадіоприймач, радіотелемеханіка, радіотеплолокачія, радіотермографія, радіофототелеграф, стереофотографія, біогеохімія, геліогеофізика, гідрометеослужба, електротепловентилятор.

У сучасній українській мові афіксоїди становлять проміжну афіксоподібну морфему. Залежно від позиції у слові і зміни форми афіксоїди можуть мати статус префіксоїдів і суфіксоїдів. Афіксоїди активізують аглютинативні тенденції української мови.

Вивчення словотворчого потенціалу афіксоїдів в українській мові передбачає максимальне врахування здобутків наукових шкіл щодо розглядуваного мовного явища.

Навчальна діяльність майбутніх філологів за діяльнісного підходу характеризується єдністю цілей i напрямів навчальнопізнавальної, наукової і виховної роботи у ВНЗ: реалізацією взаємозв'язку i наступності форм i методів фахової підготовки студентів; безперервністю науково-дослідницької діяльності; поглибленням предметних знань студентів i $і$ х послідовне 
використання у процесі взаємонавчання; формуванням науковометодологічного світогляду.

\section{Література}

1. Авдєєва С. Л. Нульова парадигма в сучасній українській літературній мові / С. Л. Авдєєва // Лінгвістичні студії : зб. наук. праць. - Донецьк : ДонНУ, 2003. Вип. 11. - Част. 1. - С. 11-20.

2. Безпояско О. К. Граматика української мови : Морфологія / Безпояско О. К., Городенська К. Г., Русанівський В. М. - К. : Либідь, 1993. - 335 с.

3. Жлуктенко Ю. О. Мовні контакти / Ю. О. Жлуктенко. - К. : Вид-во Київ. ун-ту, 1966. $-135 \mathrm{c}$.

4. Клименко Н. Основи морфеміки сучасної української мови / Н. Клименко // Українська мова та література. - 2000. - № 32. - 95 с.

5. Світлична Є. I. Латинська мова : [підручник] / Є. І. Світлична, I. О. Толок // Тривіальні (умовні) назви лікарських засобів. - [3-тє вид.]. - К. : ВД «Професіонал», 2007. - С. 77-90.

6. Сучасна українська літературна мова / за ред. А. П. Грищенка. - К. : Вища школа, 2002. - 439 с.

7. Сучасна українська літературна мова : Лексика і фразеологія. - К. : Наук. думка, 1973. - 438 с.

8. Словник іншомовних слів. - К. : Головна редакція УРЕ, 1985. - 780 с. 